needs of Harvard undergraduates in addition to a good general collection of books that it makes readily available."

The Catalogue contains more than 39,000 titles arranged in classified form by the Lamont Library classification scheme. It is provided with a brief table of contents in which the structure of the classification scheme is clearly outlined, an author index, and a subject index. Individual entries are brief but adequate. The general format is simple, unpretentious and attractive. Altogether, from a physical point of view this book appears to meet the criteria for a good printed catalog.

Philip J. McNiff, Lamont Librarian, prepared the Catalogue with the assistance of Roland H. Moody and William B. Ernst, Jr. of the Lamont staff, and George W. Cottrell, Jr., Editor of the Harvard University Library. Its preparation was made possible by a grant from the Carnegie Corporation.

As McNiff emphasizes in his introductory statement this is the catalog of a working collection; it does not attempt to represent an ideal book collection for a liberal arts college. Consequently, it would be impertinent to criticize or appraise this catalog in the light of the criteria one might apply to the ideal or theoretical type of book best exemplified by the Shaw ${ }^{1}$ list.

As a working list of books for undergraduates in an eminent liberal arts college, the Catalogue automatically achieves a place of importance for college and university librarians. It represents the experience of an excellent library staff working in conjunction with a first rate liberal arts faculty in the determination of book selection policy and the actual selection of books. Added to this condition has been the observation of the use made, of the collection so selected, by $\mathrm{Har}$ vard undergraduates.

The method of book selection for the Lamont collection is described in some detail in an article entitled "The Selection of Books for Lamont," by Edwin E. Williams. ${ }^{2}$ The subsequent refinement of the original lists and the limitations and general coverage of the present Catalogue are briefly but simply set forth in the introduction to the Catalogue.

Librarians will find much to study and

1 Shaw, Charles B. A List of Books for College I Shaw, Charles B. A List of Books for College
Libraries. Chicago, American Library Association, I 9 ? I.

${ }_{2}^{2} \dot{H}$ arvard Library Bulletin, 3:386-94, Autumn, 1949. perhaps to emulate in the selection, organization and presentation of this list. Despite its limitations, they will find the catalogue a highly suggestive and useful guide in evaluating their collections. In the arrangement of the titles and forms of entry there will be found useful suggestions; in the simple format and economical method of production, encouragement for additional projects of this sort.-Morris A. Gelfand, Queens College Library.

\section{Problems in Psychology}

Professional Problems in Psychology. By Robert S. Daniel and C. M. Louttit. New York, Prentice-Hall, 1953. 416 pp. \$5.50.

Undoubtedly, a more significant title for this book might have been "A Guide to the Literature of Psychology," since the chief professional problems it takes up are those of library research, manuscript preparation, outlets for publication, etc. In addition, the authors have included material intended to help the student in psychology acquire professional perspective, around which the entire book centers.

There has not been a guide to the literature of psychology since Louttit in 1932 published his Handbook of Psychological Literature, of which Professional Problems is partly a revision and expansion. Louttit (University of Illinois) is editor of Psychological $A b$ stracts, and Daniel teaches a course in Studies in Professional Problems at the University of Missouri. Their successful collaboration has resulted in a handy little reference volume that ranges from such basic information as where to put" the period when your sentence ends in parentheses to membership requirements for the American Psychological Association.

The book proper is divided into four parts. The first of these orients the reader in the growth of psychology as a profession. The fourth and final part reinforces the emphasis on "professionalization" and discusses fields of training, job opportunities, legal, ethical, and public relations, and professional organizations.

Parts 2 and 3 , the major portion of the book, comprise the guide to psychological literature. The authors investigate the important sources of information and how to 
find them in libraries; in explaining classification schemes, that of the Library of Congress is dismissed rather casually, but Dewey's and, understandably, Louttit's own classification schemes are gone into in some detail. Familiarity with library arrangement and willingness to enlist the aid of the reference librarian are recognized as prerequisites to any research job.

In the chapters covering scientific reporting, all forms of written and oral communication that the psychologist is likely to need are clearly and comprehensively treated. The authors give explicit instructions for preparing standard manuscripts and bibliographies, prefaced by the warning that specific journals have individual requirements which must be met when one expects publication in them. Twenty major psychological journals are described as to frequency, area of interest, policy for distributing reprints, cost (if any) to the author, and publication lag; there is also a section dealing with the most frequent reasons why editors reject manuscripts.

Besides a list of references at the end of each chapter, there are appendices: lists of 306 reference books (annotated) and 33I journals of value to the psychoiogist; sources of books, tests, apparatus, etc.; and a glossary of abbreviations for not only psychological terms but also names of organizations, tests, and physical measurements.

The usefulness of this reference tool to those with any connection with psychological literature is marred only by the unfortunately inevitable fact that the material has already begun to be dated. The bibliographies include almost nothing later than 1952. Descriptions of research sources have altered, e.g. Louttit's own Psychological Abstracts has since changed from monthly to bi-monthly publication. In spite of this drawback, Professional Problems in Psychology will prove a valuable addition to the guides to the literature of the sciences.-James C. Dance, Psychology Library, Columbia University.

\section{Cataloging Catholic Material}

A Manual of Cataloging Practice for Catholic Author and Title Entries. By Oliver

L. Kapsner, O.S.B. Washington: Catholic University of America Press, 1953. $\$ 2.00$.

Librarian at St. John's Abbey, College- ville, Minnesota, for some twenty years and research cataloger at the Catholic University of America since September 195I, Father Kapsner has long been familiar with the problems of librarians dealing with collections of Catholic material. Out of this experience with theological and religious literature have already come his Catholic Subject Headings (now appearing in a third edition), Catholic Religious Orders, and $A$ Benedictine Bibliography. This Manual has been developed as a further aid to catalogers in Catholic libraries and is intended as a guide and arbiter in those areas of cataloging practice which are not adequately covered in existing cataloging tools.

As the subtitle indicates, the entries and rules for entry are intended through adaptations, revisions, and new provisions to be "supplementary aids to the ALA and Vatican Library Cataloging rules," or, as in the case of the Vatican rules, to indicate an expansion or modification to suit the needs of Catholic libraries in America. The entries cover Bible; Apocryphal Books of the Bible; Liturgical Books of the Latin and Eastern Rites; PrayerBooks; Catechisms, Hymns, Indulgences; Imitatio Christi; Index Librorum Prohibitorum; Saints; Popes; Councils and Synods; Pastoral Letters; Catholic Church and Holy See; Personal and Corporate Names in Religious Orders; and Monastic Rules. Under each topic the corresponding ALA and Vatican rules are specified, with descriptions of material belonging to that category, rules for entry with generous examples of entries and sample cards, and suggested subject headings, particularly form headings.

For many of the entries, as Imitatio Christi and Index Librorum Prohibitorum, no variation from present procedure is proposed except minor changes such as the addition of a date to the entry. In other cases, variations from ALA rules and Library of Congress practice are indicated, with suggestions to catalogers in Catholic libraries for bringing these entries into conformity with Catholic usage, as for Biblical and Apocryphal Books of the Bible (though we note here that those Books not included in the Catholic canon would be treated as "anonymous classics" and entered under "accepted names").

At other points, as in entries for liturgical literature, entries under Catholic Church, and for personal names in religion, complete 